\title{
Penggunaan media film Umar Bin Khattab dalam pembelajaran Sejarah Kebudayaan Islam
}

\author{
Dudi Budi Astoko \\ Universitas Islam Negeri Raden Mas Said, Indonesia \\ dudiastoko5@gmail.com
}

\begin{abstract}
This research aims to find out the effectiveness of the Learning Process of Islamic Cultural History students, through the media Film Umar bin Khattab. The subjects of this study were students of class X-IIS-4, Class X-IIS-2, and Class X-IIS-3, while the object of the research was SKI Learning at MAN I Magelang. divided into 8 classes totaling 631 students. The sample taken in this study was 76 students, consisting of 40 classes of X-IIS-4 as an experimental group and 36 students of class X IIS-2 as a control group. This form of research is pure experimental research (true experimental design). That is research using randomized subject design, Pre-test-Post-test Control Group Design, with experimental group and control group. The use of Umar Bin Khattab film media in the process oflearning Islamic cultural history in Madrasah Aliyah Negeri 1 Magelang has a high level of effectiveness.
\end{abstract}

Keywords: film, Islamic Cultural History, true experiment

\begin{abstract}
Abstrak
Penelitian ini bertujuan untuk mengetahui efektivitas Proses pembelajaran Sejarah Kebudayaan Islam Siswa, melalui media Film Umar bin Khattab. Subjek dari penelitian ini adalah siswa kelas X-IIS-4, Kelas X-IIS-2, dan Kelas X-IIS-3, sedangkan objek penelitian dari penelitian ini adalah Pembelajaran SKI di MAN I Magelang. yang terbagi dari 8 kelas berjumlah 631 siswa. Sampel yang diambil dalam penelitian ini sebanyak 76 siswa, terdiri dari 40 kelas X-IIS-4 sebagai kelompok eksperimen dan 36 siswa kelas X IIS-2 sebagai kelompok kontrol. Bentuk penelitian ini adalah penelitian eksperimen murni (true experimental design). Yaitu penelitian yang menggunakan desain Randomized Subject, Pre-test-Post-test Control Group Design, dengan kelompok eksperimen dan kelompok kontrol. Penggunaan media film Umar Bin Khattab dalam proses pembelajaran sejarah kebudayaan Islam di Madrasah Aliyah Negeri 1 Magelang memiliki tingkat efektivitas yang tinggi.
\end{abstract}

Kata Kunci: eksperimen murni, film, Sejarah Kebudayaan Islam 


\section{Pendahuluan}

Konsep Pendidikan Islam didasari kepada suatu acuan bahwa Islam sebagai agama dan sistem kehidupan. Pendidikan menurut Islam merupakan suatu upaya pendidikan agama dan ajaran Islam beserta nilai nilainya, agar menjadi pandangan dan sikap hidup seseorang (Idris, 2005). Dengan demikian permasalahan yang dihadapi adalah proses pembelajaran Sejarah Kebudayaan Islam yang sampai saat ini belum berhasil memperlihatkan pembentukan perilaku positif peserta didik salah satu hal yang menyebabkan belum berhasilnya adalah dalam hal metodologi pembelajaran yang dilaksanakan oleh guru. Hal ini antara lain karena metode yang banyak dipakai adalah model ekspositori (Abdurrahman, 2007).

Apabila kualitas pembelajaran tidak ditingkatkan, kemungkinan besar tujuan pembelajaran PAI pun kurang sesuai dengan harapan. sebagaimana yang dirumuskan oleh Departemen Pendidikan Nasional, bahwa tujuan PAI adalah membentuk peserta didik yang beriman dan bertakwa kepada Allah SWT, memiliki pengetahuan yang luas tentang Islam dan berakhlakul karimah (Direktorat Pembinaan Sekolah Menengah, 2003). Keberadaan Pendidikan Agama Islam dimaksudkan membentuk peserta didik menjadi manusia yang beriman dan bertakwa kepada Tuhan Yang Maha Esa. Serta berakhlak mulia yang mencakup Etika, Budi Pekerti atau moral.

Permasalahan yang tampak dan nyata dan diakui oleh para ahli pendidikan dewasa ini adalah pendidikan Agama yang diajarkan disekolah umum ternyata kurang berhasil untuk mengembangkan pribadi-pribadi yang taat dan berakhlak mulia. Bukti-bukti yang diajukan untuk memperkuat pernyataan tersebut antara lain. Kenyataan adanya peserta didik yang tidak mampu membaca Al-Qur'an dengan baik meskipun sudah duduk dibangku SMA belum bisa melaksanakan salat dengan baik, tidak melaksanakan puasa pada bulan Ramadan, tidak menunjukkan perilaku terpuji, banyaknya perilaku Asusila dan penggunaan obat terlarang dan minum minuman keras di kalangan pelajar. Kesimpulannya pendidikan agama belum mampu menumbuhkan sikap positif dalam diri anak yang berguna bagi kemaslahatan masyarakat. Menurut Darajat (2001), untuk mencapai tujuan pendidikan dalam proses belajar mengajar, paling tidak ada dua aspek yang perlu mendapatkan perhatian, yaitu didaktik dan metodik.

Didaktik adalah ilmu menanamkan pengetahuan kepada murid dengan cara yang cepat dan tepat sehingga anak dapat dengan mudah menangkapnya atau dengan Istilah lain Ilmu yang memberikan uraian tentang kegiatan proses mengajar yang menimbulkan proses belajar. Sedangkan metodik adalah bagian dari didaktik yang membicarakan tentang pelaksanaan cara mengajar, atau cara guru menyajikan bahan pelajaran kepada murid (Zuhairini. 2003)

Kenyataan di lapangan bahwa guru-guru sejarah kebudayaan Islam, jarang yang mau mencermati efektivitas penggunaan strategi mengajar. Perhatiannya lebih fokus pada 
buku pegangan yang dipergunakan. Di samping itu dalam proses pembelajaran mereka kebanyakan lebih dominan menggunakan metode ceramah.

Hal ini bukan berarti menganggap bahwa metode ceramah kurang bermanfaat, namun dilihat dari aspek psikologis kurang dapat memobilisasikan seluruh potensi berpikir, sikap dan ketrampilan anak didik. Dengan kata lain. bila pengajaran agama Islam hanya menggunakan metode ceramah berarti hanya menyentuh aspek kognitif saja (menghafal dan mengetahui) padahal inti PAI adalah keimanan yang lebih berdimensi afektif dengan sarana utama hati nurani yang harus diterapkan dalam kehidupan seharihari. Untuk itu hendaklah PAI bersifat Integralistik (menyeluruh) yang menyentuh semua ranah.

Dalam Undang-undang No. 20 Tahun 2003 tentang Sistem Pendidikan Nasional (SISDIKNAS) dikemukakan bahwa pendidikan adalah usaha sadar dan terencana untuk mewujudkan suasana belajar dan proses pembelajaran agar peserta didik secara aktif mengembangkan potensi dirinya untuk memiliki kekuatan spiritual keagamaan. pengendalian diri. kepribadian, kecerdasan, akhlak mulia, serta ketrampilan yang diperlukan dirinya, masyarakat, bangsa dan Negara (pasal 1 ayat 1) dalam hal ini terkandung makna bahwa pendidikan merupakan upaya dari generasi tua untuk mengembangkan potensi generasi muda baik secara spiritual. intelektual maupun psikomotor yang pada gilirannya akan memberi manfaat bagi generasi muda bagi kehidupan bermasyarakatnya.

Pada pasal 3 dalam Undang-undang yang sama, dikemukakan juga bahwa pendidikan nasional berfungsi mengembangkan kemampuan dan membentuk watak serta peradaban bangsa, yang bermartabat dalam rangka mencerdaskan kehidupan bangsa, bertujuan untuk berkembangnya potensi peserta didik agar menjadi manusia yang beriman dan bertakwa kepada Tuhan Yang Maha Esa. berakhlak Mulia, sehat, berilmu, cakap, kreatif, mandiri. dan menjadi warga Negara demokratis serta bertanggung jawab. Bila fungsi dan tujuan pendidikan nasional ini dihubungkan dengan pengertian sejarah, maka sejarah mempunyai fungsi utama mengabadikan pengalaman masyarakat masa lampau yang dapat menjadi bahan pertimbangan bagi masyarakat dalam memecahkan masalah yang dihadapinya.

Untuk itu dibutuhkan suatu model pembelajaran PAI yang di dalamnya ada pelajaran Sejarah Kebudayaan Islam yang bukan hanya menyuruh peserta didik untuk menghafal nilai-nilai normatif, disampaikan lewat ceramah dan diakhiri dengan ulangan, tetapi yang mengarahkan peserta didik mampu menguasai ketrampilan berpikir, karena memang seharusnya learning itu berisi thinking dan juga values. Atas dasar Itulah dipilih media yang tepat dalam pembelajaran SKI. dengan maksud sebagai suatu upaya untuk meningkatkan kualitas pembelajaran. 
Sejarah pada umumnya begitu juga dengan sejarah kebudayaan Islam masih sangat diperlukan dalam kehidupan yang serba berubah di masa depan namun ada pertanyaan besar yang penting untuk dijawab adalah Sejarah macam apa yang perlu diajarkan dan bagaimana mengajarkannya? Pendidikan sejarah tidak hanya dimaksudkan agar siswa tahu dan hafal tentang peristiwa masa lalu bangsanya, tetapi lebih dari itu siswa dituntut untuk dapat merefleksi diri dari pemahaman sejarahnya, sehingga dalam dirinya tumbuh dan berkembang nilai-nilai cinta tanah air, rasa memiliki, rasa bangga terhadap bangsanya.

Hal ini sejalan dengan apa yang diungkapkan oleh Ismaun (2001) bahwa apabila siswa memiliki kesadaran sejarah maka siswa akan mampu mengidentifikasi nilai-nilai yang terkandung dalam peristiwa sejarah yang mampu mengembangkan nilai-nilai tersebut menjadi milik dirinya. Kesadaran sejarah menurut Widja (2002) adalah kesadaran yang menunjukkan satu tingkat penghayatan pada makna serta hakikat sejarah (dinamika sejarah) sebagai tuntunan menghadapi masa kini dan masa yang akan datang.

Menurut Wiriaatmadja (2002), kemampuan berpikir peserta didik melalui sejarah dikembangkan tidak hanya dengan cara menghafal siapa, kapan, dan di mana. Melainkan yang perlu lebih mantap dan sering dilakukan adalah memaparkan bagaimana dan mengapa dari sebuah peristiwa sejarah sehingga peserta didik dilatih dalam aspek kognitif yang lebih tinggi dari pengetahuan saja. Pernyataan ini diperkuat juga oleh Nash dan Crabtree (1994) dalam bahwa pembelajaran sejarah saat ini kita kenal dengan pelajaran yang hanya memberikan pengetahuan tentang fakta. tanggal, nama. tempat, peristiwa, dan ide. Sesungguhnya pemahaman pengajaran sejarah yang benar adalah yang memberikan siswa ketrampilan dalam berpikir sejarah. mengangkat masalah dan untuk memberikan fakta-fakta yang tetap dalam menyokong jawabannya.

Pengajaran sejarah menurut Wiriaatmadja. akan membangkitkan kesadaran empati (empatic awareness) di kalangan peserta didik, yaitu sikap simpati dan toleransi terhadap orang lain yang disertai dengan kemampuan mental untuk imajinasi dan kreativitas, jika sejarah dipahami dengan benar oleh peserta didik. Pengajaran sejarah nasional disekolah, bagaimanapun, akan memperkenalkan peserta didik kepada pengalaman kolektif dan masa lalu bangsanya. Pengajaran ini juga membangkitkan kesadaran dalam kaitannya dengan kehidupan bersama dalam komunitas yang lebih besar, sehingga tumbuh kesadaran kolektif dalam memiliki kebersamaan dalam sejarah. Proses pengenalan diri inilah yang merupakan titik awal dari timbulnya rasa harga diri. kebersamaan, dan keterikatan (sense of solidarity), rasa keterpautan dan rasa memiliki (sense of belonging), kemudian rasa bangga (sense of pride) terhadap bangsa dan tanah airnya sendiri. 
Sedangkan Widja menyatakan bahwa keadaan masyarakat saat ini yang kurang siap menghadapi perubahan sesungguhnya merupakan sebuah wujud ketidaksiapan mental dari generasi kita. Kesiapan mental ini sebenarnya dapat dikembangkan melalui pemahaman makna dinamika sejarah yang benar dengan kata lain akar sebenarnya dari permasalahan itu adalah tidak lain merupakan kegagalan atau ketidaksiapan kita mengembangkan kewaspadaan sejarah (historical awareness) dalam menghadapi setiap kejutan yang dibawa oleh setiap tantangan zaman, akibat kurang dipahaminya sejarah dengan benar.

Belajar sejarah merupakan wahana pendidikan siswa agar mampu menemukan jati diri pribadi, masyarakat, dan bangsanya. Melalui belajar sejarah pula siswa dibimbing untuk menyadari fungsinya dalam masyarakat dan akhirnya diharapkan menjadi manusia yang mau dan biasa melakukan aktivitas yang bermanfaat di dalam kehidupannya sehari hari dan berpartisipasi dalam membangun masyarakat yang demokratis (Widja, 2002).

Kondisi pembelajaran sekolah di Indonesia yang didominasi oleh kegiatan ceramah (ekspositori) atau khotbah tentang kisah masa lampau. agaknya menjadi salah satu pemicu pendapat-pendapat mengenai kebosanan dalam pembelajaran sejarah dan kurangnya kesadaran kebangsaan siswa. Tuntutan pengajaran sejarah yang mengharuskan siswa untuk memiliki kemampuan berpikir kesejarahan dan kesadaran sejarah setelah proses pembelajaran sejarah, akan sulit terwujud jika Guru masih menggunakan metode pengajaran yang monoton oleh karena itu guru harus dapat memahami kebutuhan peserta didik dan kreatif menggunakan metode pengajaran, bahan ajar, media pengajaran, lingkungan peserta didik, dan lain-lain, agar tujuan peserta didik memiliki kesadaran sejarah dapat terwujud.

Berdasarkan hasil observasi awal di MAN Magelang. ketiga pembelajaran SKI berlangsung, dengan tidak menggunakan media pembelajaran, pembelajaran terasa menjenuhkan. Peserta didik merasa bosan dan tidak tertarik dengan materi yang disampaikan oleh guru. Apalagi pelajaran sejarah, di dalam pikiran peserta didik sudah tertanam hafalan tentang tahun, peristiwa dan tokoh. Akibat dari kejenuhan tersebut maka materi tidak dapat dipahami dengan baik. Akibat dari itu maka prestasi belajar SKI akan rendah. Padahal KKM yang diterapkan 75. Namun prestasi belajar anak masih jauh dari KKM yang telah ditetapkan. Rata-rata nilai SKI adalah 65 oleh karena itu perlu dicari cara untuk meningkatkan semangat anak dalam belajar SKI.

Salah satu cara yang dapat digunakan oleh guru adalah melalui pemanfaatan media pembelajaran dalam hal ini media Film dalam proses pembelajaran Sejarah pengembangan arus teknologi dan informasi sebagai bagian dari proses globalisasi saat ini sudah tidak dapat kita bendung dan hindari lagi. Setiap orang, sekelompok sosial budaya. dan masyarakat menurut Hasan memiliki akses untuk mempengaruhi dan 
terpengaruh melalui alat-alat komunikasi canggih seperti televisi dan radio yang dapat menerima dan mengirim pesan ke seluruh dunia. Komputer yang dapat berhubung melalui internet ke berbagai sumber informasi yang tak terbatas, serta telepon seluler yang sangat memberi peluang untuk berkomunikasi tanpa keterbatasan ruang dan waktu. Di samping ketersediaan alat menyimpan informasi seperti disket (audio, Video), CD, VCD, beserta alat untuk membacanya telah memberi pengaruh terhadap berbagai aspek kehidupan manusia (Hamid, 2003).

Beberapa penelitian yang relevan dengan penelitian ini di antaranya yang dilakukan Muharria dkk. (2016) menyatakan bahwa penerapan media film pendek dapat memberikan pengaruh yang signifikan terhadap hasil belajar siswa. Dari hasil analisis data yang dilakukan oleh peneliti melalui Uji-t. Bahwa hasil belajar siswa dari kelas eksperimen dan kelas kontrol menunjukkan adanya pengaruh yang baik dari kelas eksperimen. Di mana pada kelas eksperimen memperoleh hasil belajar siswa lebih tinggi dari pada kelas kontrol. Hal ini disebabkan karena dalam penerapan media film pendek siswa dituntut menganalisis film yang telah ditayangkan sesuai dengan materi kelas $\mathrm{X}$ Matematika Ilmu Alam (MIA) 2 Sebagai kelas eksperimen yang telah diterapkan media pembelajaran film pendek memiliki skor lebih tinggi. Selain itu, Resmiati (2010) dalam penelitiannya menyatakan ada pengaruh positif yang signifikan penggunaan media film dokumenter dalam meningkatkan prestasi belajar sejarah. Secara ringkas berdasarkan penelitian yang telah ada yang relevan dengan penelitian ini, dapat dirangkum bahwa Media Film sangat mempengaruhi dalam proses pembelajaran sehingga siswa dapat dengan mudah memahami dan menguasai materi ilmu sejarah dengan lebih jelas dan dapat meningkatkan pemahaman siswa.

\section{Metode Penelitian}

Penelitian ini menggunakan jenis penelitian eksperimen sedangkan pendekatan yang digunakan adalah pendekatan kuantitatif. Pendekatan penelitian yang digunakan dalam penelitian ini adalah penelitian Kuantitatif yaitu data yang diperoleh dengan bentuk angka-angka dengan analisis statistik. Penelitian ini merupakan penelitian Eksperimen murni (true eksperimental design) penelitian ini menggunakan design Randomized Subject, Pre-test-Post-test Control group design, menggunakan dua kelompok eksperimen dan kelompok kontrol. Kelompok Eksperimen diberikan suatu tindakan yaitu pembelajaran dengan media film Umar Bin Khattab sedangkan kelompok kontrol tidak diberikan tindakan apa pun sebagai pengontrol kelompok eksperimen. Rancangan penelitian tersebut memiliki pola yang digambarkan sebagai berikut:

Tabel 1 Rancangan penelitian

\begin{tabular}{ccccc}
\hline & Group & Pre-test & Variabel Terikat & Post-test \\
\hline (R) & Eksperimen & YI & X & Y2 \\
(R) & Kontrol & YI & - & Y2 \\
\hline
\end{tabular}


Keterangan:

$\mathrm{X}$ : ada treatment

- $\quad$ : tidak ada treatment

Variabel yang digunakan dalam penelitian ini meliputi variabel independen dan variabel dependen. Variabel Independen (X) dalam penelitian ini variabel independen berupa tindakan yaitu media film Umar Bin Khattab. Sedangkan Variabel Dependen (Y) dalam penelitian ini adalah pembelajaran SKI

Subjek dari penelitian ini adalah siswa kelas X-IIS-4, Kelas X-IIS-2, dan Kelas X-IIS-3, sedangkan objek penelitian dari penelitian ini adalah Pembelajaran SKI di MAN I Magelang. Populasi dalam penelitian ini adalah siswa kelas X MAN 1 Magelang yang terbagi dari 8 kelas berjumlah 631 siswa. Sampel yang diambil dalam penelitian ini sebanyak 76 siswa, terdiri dari 40 kelas X-IIS-4 sebagai kelompok eksperimen dan 36 siswa kelas X IIS-2 sebagai kelompok kontrol. Adapun sampel yang peneliti gunakan berdasarkan teori yang disampaikan Arikunto (1998) untuk populasi yang lebih dari 100, sampel dapat diambil sebanyak $10 \%$ atau lebih.

Penentuan sampling menggunakan purposive sampling. Instrumen penelitian yang diperlukan dalam penelitian ini yaitu pedoman observasi, lembar angket dan lembar tes formatif. Instrumen yang baik adalah instrumen yang valid dan reliabel. Dalam hal ini kuesioner diukur validitas dan reliabilitasnya sebelum dilakukan penelitian. Dalam penelitian ini uji validitas dilakukan pada instrumen kuesioner variabel penggunaan media Umar Bin Khattab. Kuesioner ini telah diujicobakan terlebih dahulu pada 39 siswa di kelas lain yang tidak digunakan sebagai sampel. Teknik yang digunakan dalam mengumpulkan data adalah observasi dan angket. Observasi yang dilakukan meliputi kegiatan pemusatan perhatian terhadap sesuatu objek dengan menggunakan seluruh alat indra (Sukandarrumidi, 2002). Sedangkan Angket adalah sejumlah pertanyaan tertulis yang digunakan untuk memperoleh informasi dari responden tentang efektivitas media film Umar Bin Khattab dalam pembelajaran SKI dikelas X MAN I Magelang.

Penelitian ini menggunakan data kualitatif yang diangkakan selanjutnya disebut sebagai kuantitatif yang berbentuk data interval yang dikategorikan dalam empat tingkatan dengan menggunakan skala likert.

Tabel 2 Bobot penilaian angket

\begin{tabular}{cc}
\hline Jawaban & Bobot Nilai \\
\hline A & 5 \\
B & 4 \\
C & 3 \\
D & 2 \\
E & 1 \\
\hline
\end{tabular}


Peneliti memberikan dua macam tes. yaitu Pre-test dan Post-test, yakni model soal yang terkait dengan materi yang telah dipelajari sebelum dan setelah pembelajaran menggunakan media film Umar bin Khattab dengan tujuan untuk melihat sejauh mana efektivitas penggunaan media film Umar bin Khattab dalam pembelajaran SKI yang tercermin dalam prestasi belajar siswa.

Uji asumsi yang digunakan dalam penelitian ini adalah uji normalitas dan homogenitas. Uji normalitas digunakan untuk mengetahui distribusi data bersifat normal atau tidak. Uji normalitas dalam penelitian ini menggunakan teknik Kolmogarov smirnov test dengan bantuan program komputer SPSS 20 for windows. Hasil uji normalitas disajikan dalam tabel berikut.

Tabel 3 Hasil Uji Normalitas

\begin{tabular}{cccc}
\hline Data & Nilai Statistik & P value & Keterangan \\
\hline Hasil Observasi & & & \\
Eksperimen & 0.077 & 0.200 & Normal \\
Kontrol & 0.086 & 0.163 & Normal \\
Hasil Angket & & & \\
Pre-test & 1,214 & 0.105 & Normal \\
Pos test & 1,135 & 0.152 & Normal \\
Hasil tes & & & \\
Pre-test_kontrol & -175 & 0.695 & Normal \\
Pos test_kontrol & -168 & 0.460 & Normal \\
Pre-test_eksperimen & -192 & 0.755 & Normal \\
Posttest_eksperimen & $\_163$ & 0.494 & Normal \\
\hline
\end{tabular}

Berdasar tabel di atas diketahui bahwa semua nilai statistik memiliki nilai p value > 0,05 dengan demikian disimpulkan bahwa data yang digunakan untuk penelitian terdistribusi normal.

Uji Homogenitas digunakan untuk mengetahui data penelitian yang digunakan bersifat homogen atau tidak. Uji Homogenitas dalam penelitian ini menggunakan teknik one way anova dengan bantuan program komputer SPPS 20 for windows. Hasil uji normalitas disajikan dalam tabel berikut.

Tabel 4 Hasil Uji Homogenitas

\begin{tabular}{cccc}
\hline Data & Levene statistic & P value & Keterangan \\
\hline Hasil tes (Pre-test) & 0,470 & 0,495 & homogen \\
\hline
\end{tabular}

Berdasarkan tabel di atas diketahui bahwa semua nilai levene statistic memiliki nilai Pvalue $>$ 0,05 dengan demikian disimpulkan bahwa kedua kelompok yang digunakan dalam penelitian ini adalah homogen.

Sesuai dengan hipotesis yang diajukan. untuk mengetahui efektivitas media film Umar bin Khattab dalam pembelajaran SKI, digunakan analisis statistik independent 
sample $t$ test dan paired sample $t$ test. semua data diolah dengan bantuan komputer program SPSS for windows versi 20.

\section{Hasil dan Pembahasan}

\section{A. Hasil Penelitian}

Hasil penelitian tentang prestasi belajar Sejarah Kebudayaan Islam dalam penelitian ini diukur menggunakan instrumen berupa tes pilihan ganda yang diberikan kepada kedua kelompok yaitu kelas eksperimen. maupun kelas kontrol. Kelompok eksperimen sebanyak 40 siswa sedangkan kelompok kontrol sejumlah 36 siswa.

\section{Efektivitas Media Film Umar Bin Khattab dalam Pembelajaran SKI ditinjau dari Hasil Observasi}

Observasi dalam penelitian ini adalah observasi langsung. sistematis atau partisipan yang dilakukan oleh peneliti terhadap peserta didik saat pembelajaran SKI berlangsung dengan pedoman observasi sebagai instrumen pengamatan. kisi-kisi Pedoman Observasi dimaksud sebagai berikut:

Tabel 5 Kisi-kisi Pedoman Observasi

\begin{tabular}{cllll}
\hline \multirow{2}{*}{ No. } & \multicolumn{1}{c}{ Objek yang diamati } & \multicolumn{3}{c}{ Skor } \\
\cline { 3 - 5 } & \multicolumn{1}{c}{1} & 2 & 3 & 4 \\
\hline 1 & Perhatian siswa terhadap pembelajaran & & & \\
2 & Minat siswa terhadap pelajaran & & & \\
3 & Aktivitas siswa & & & \\
4 & Semangat belajar & & & \\
5 & Suasana belajar riuh menyenangkan & & & \\
6 & Keadaan pembelajaran tertib & & & \\
7 & Pelaksanaan pembelajaran lancar & & & \\
\hline
\end{tabular}

Observasi yang dilakukan adalah observasi partisipan. Observasi ini digunakan untuk mengetahui jalanya pembelajaran SKI. Adapun deskripsi hasil observasi pembelajaran SKI disajikan dalam tabel berikut:

Tabel 6 Proses Pembelajaran Kelompok Eksperimen dan Kontrol

\begin{tabular}{ccccc}
\hline Kelompok & $\mathbf{N}$ & Minimum & Maximum & Mean \\
\hline Eksperimen & 40 & 57 & 80 & 69 \\
Kontrol & 36 & 47 & 71 & 53,9 \\
\hline
\end{tabular}

Berdasarkan tabel di atas diketahui bahwa pada kelompok eksperimen diketahui nilai minimum yang diperoleh sebesar 57 , nilai maksimum diperoleh nilai sebesar 80 dan nilai rata-rata diperoleh sebesar 69 , pada kelompok kontrol diperoleh nilai minimum sebesar 47, nilai maksimum sebesar 71 dan diperoleh nila rata-rata sebesar 53,9 
Langkah selanjutnya adalah membagi pembelajaran SKI menjadi tiga kategori yaitu tinggi, sedang dan rendah dengan rumus interval kelas kategori pembelajaran SKI mendasarkan pada mean ideal dan standar deviasi ideal (SDI).

Berdasarkan harga Mi dan SDI dapat diidentifikasi kategori bawah tingkat pembelajaran SKI sebagai berikut:

Tinggi dengan Skor: $>\mathrm{Mi}+1,5 \mathrm{SDi}=>68$

Sedang dengan skor: Mi-1,5 SDi sampai Mi + 1,5 SDi = 37-68

Rendah dengan skor: $<\mathrm{Mi}-1,5 \mathrm{SDi}=<37$

Berdasarkan interval kelas tersebut, maka diperoleh tingkat pembelajaran SKI berdasarkan hasil observasi pada kedua kelompok adalah sebagai berikut:

Tabel 7 Hasil observasi pembelajaran kelompok eksperimen dan kontrol

\begin{tabular}{ccccccc}
\hline \multirow{2}{*}{ No. } & \multirow{2}{*}{ Kategori } & Nilai & \multicolumn{2}{c}{ Eksperimen } & \multicolumn{2}{c}{ Kontrol } \\
\cline { 3 - 6 } & & & $\mathrm{F}$ & $\%$ & $\mathrm{~F}$ & $\%$ \\
\hline 1 & Tinggi & $69-84$ & 21 & $52,5 \%$ & 5 & $13,9 \%$ \\
2 & Sedang & $37-68$ & 19 & $47,5 \%$ & 31 & $86,1 \%$ \\
3 & Rendah & $21-37$ & 0 & $0,0 \%$ & 0 & $0,0 \%$ \\
& & Jumlah & 40 & 100 & 36 & 100 \\
\hline
\end{tabular}

Berdasarkan tabel di atas dapat diketahui bahwa nilai tertinggi pada kelompok eksperimen adalah kategori tinggi. Pada kelompok kontrol nilai tertinggi hasil observasi dalam kategori sedang hal tersebut berarti pembelajaran SKI dengan media film Umar bin Khattab pada kelompok Eksperimen lebih baik dibandingkan dengan pembelajaran SKI pada kelompok kontrol yang menggunakan metode konvensional. \

\section{Efektivitas Media Film Umar Bin Khattab dalam Pembelajaran SKI ditinjau dari Hasil Angket}

Angket dalam penelitian ini digunakan untuk mengetahui efektivitas media film Umar Bin Khattab pada kelompok eksperimen pembagian angket dilakukan setelah pembelajaran menggunakan media film Umar Bin Khattab selesai dilaksanakan. Adapun deskripsi hasil jawaban angket siswa kelompok eksperimen disajikan dalam tabel berikut:

Tabel 8 Hasil Jawaban angket siswa kelompok eksperimen

\begin{tabular}{ccccc}
\hline Kelompok & $\mathbf{N}$ & Minimum & Maximum & Mean \\
\hline Pre-test & 40 & 64 & 89 & 74,38 \\
Post-test & 40 & 64 & 93 & 81,1 \\
\hline
\end{tabular}

Berdasarkan tabel di atas diketahui bahwa sebelum digunakan media film Umar Bin Khattab. jawaban rata-rata siswa sebesar 74,38 setelah digunakan media film Umar Bin Khattab dalam pembelajaran SKI, jawaban rata-rata siswa meningkat menjadi 81,1 . 
langkah selanjutnya adalah membagi hasil jawaban angket menjadi tiga kategori yaitu tinggi, sedang, dan rendah dengan rumus interval kelas. Kategori pembelajaran SKI mendasarkan pada mean ideal (Mi) dan standar Deviasi ideal (SDi). Untuk menentukan Mid an SDi dengan rumus:

$$
\begin{aligned}
& \mathrm{Mi}=1 / 2(\mathrm{ST}+\mathrm{SR}) \\
& =1 / 2(100+20) \\
& =60 \\
& \mathrm{SDi}=1 / 6(\mathrm{ST}-\mathrm{SR}) \\
& =1 / 6(100-10) \\
& =13,3
\end{aligned}
$$

Tabel 9 Hasil Angket Pembelajaran SKI

\begin{tabular}{ccccccc}
\hline \multirow{2}{*}{ No. } & Kategori & Nilai & \multicolumn{2}{c}{ Pre-test } & \multicolumn{2}{c}{ Post-test } \\
\cline { 3 - 6 } & & & $\mathrm{F}$ & $\%$ & $\mathrm{~F}$ & $\%$ \\
\hline 1 & Tinggi & $81-100$ & 7 & $17,5 \%$ & 25 & $62,50 \%$ \\
2 & Sedang & $40-80$ & 33 & $82,5 \%$ & 15 & $37,50 \%$ \\
3 & Rendah & $21-39$ & 0 & $0,0 \%$ & 0 & $0,00 \%$ \\
& & Jumlah & 40 & 100 & 40 & 100 \\
\hline
\end{tabular}

Berdasarkan tabel di atas dapat diketahui bahwa nilai tertinggi pada saat Pre-test adalah kategori sedang. Pada saat Post-test nilai tertinggi hasil angket dalam kategori tinggi. Hal tersebut berarti ada peningkatan dalam proses pembelajaran SKI dengan Media film Umar bin Khattab pada kelompok eksperimen.

\section{Efektivitas Media Film Umar Bin Khattab dalam pembelajaran SKI ditinjau dari hasil Tes}

a. Nilai SKI Pre-test

Prestasi belajar sejarah kebudayaan Islam Pre-test merupakan nilai awal di mana siswa kedua kelompok masih menggunakan metode pembelajaran ceramah. Tes ini digunakan untuk mengukur kemampuan awal siswa kedua kelompok

Tabel 10 Prestasi belajar Pre-test Kelompok Eksperimen dan Kelompok Kontrol

\begin{tabular}{cccccc}
\hline & N & Minimum & Maximum & Mean & Std. Deviation \\
\hline PRE-TEST- KONTROL & 36 & 75.00 & 82.00 & 78.7222 & 2.19885 \\
PRE-TEST-EKSPERIMENT & 40 & 75.00 & 82.00 & 78.7000 & 2.10250 \\
Valid N (listwise) & 36 & & & & \\
\hline
\end{tabular}

Berdasarkan tabel di atas diketahui bahwa pada saat Pre-test. prestasi belajar sejarah kebudayaan Islam terendah pada kelompok eksperimen adalah 75 dan nilai tertinggi mencapai 82 pada saat pada saat Pre-test nilai rata-rata kelompok eksperimen sebesar 78,70 
Pada kelompok kontrol kemampuan siswa juga hampir sama dengan kelompok eksperimen, di mana pada saat Pre-test nilai tertinggi siswa telah mencapai 82 sedangkan nilai terendah adalah 75 nilai rata-rata sejarah kebudayaan Islam pada kelompok kontrol sebesar 78,72 Hasil tersebut dapat digambarkan dalam grafik sebagai berikut

b. Nilai SKI Post-test

Tabel 11 Prestasi belajar Post-test Kelompok Eksperimen dan Kelompok Kontrol

\begin{tabular}{cccccc}
\hline & N & Minimum & Maximum & Mean & Std. Deviation \\
\hline TEST- KONTROL & 36 & 75.00 & 83.00 & 79.3611 & 2.19885 \\
TEST-EKSPERIMENT & 40 & 75.00 & 85.00 & 81.2250 & 2.21287 \\
Valid N (listwise) & 36 & & & & \\
\hline
\end{tabular}

Pada saat Post-test, nilai rata-rata kelompok eksperimen meningkat menjadi 81,23 sedangkan pada kelompok kontrol memiliki nilai rata-rata 79,36

Perbedaan peningkatan nilai antara kelompok eksperimen dan kelompok kontrol tersebut menunjukkan bahwa media film Umar Bin Khattab efektif untuk meningkatkan prestasi belajar siswa, khususnya dalam mata pelajaran sejarah kebudayaan Islam.

\section{B. Analisa Penelitian}

Analisa dalam penelitian ini digunakan untuk menguji kebenaran hipotesis yang diajukan. Hipotesis dalam penelitian ini yaitu penggunaan Media Film Umar bin Khattab Efektif dalam pembelajaran SKI di MAN I Magelang. Untuk membuktikan kebenaran hipotesis tersebut maka digunakan analisis Statistik one sample t test dan paired sampale $t$ test. Asumsi yang digunakan untuk menolak dan menerima hipotesis adalah apabila nilai t hitung memiliki tingkat probabilitas ( $\mathrm{p}$ value) $<0.05(\propto 5 \%)$ maka hipotesis diterima, berarti penggunaan media Film Umar bin Khattab efektif dalam pembelajaran SKI di MAN I Magelang.

\section{Efektivitas Media Film Umar bin Khattab dalam Pembelajaran SKI ditinjau dari hasil observasi}

Observasi dilakukan pada dua kelompok yaitu kelompok eksperimen dan kelompok kontrol pada saat pembelajaran SKI berlangsung. Observasi dilakukan berdasarkan pedoman observasi yang telah disusun sebelumnya. Hasil observasi kemudian dianalisis menggunakan analisis statistik one sample $t$ test untuk mengetahui perbedaan proses pembelajaran SKI pada kelompok Eksperimen dan kelompok kontrol. Analisis dilakukan menggunakan komputer program SPSS dengan hasil sebagai berikut

Tabel 12 Hasil Analisis Paired Sample t Test

\begin{tabular}{cccc}
\hline Kelompok & T Tes & P value & Keterangan \\
\hline Ekperimen- Kontrol & 54,66 & $0,000<0,05$ & Berbeda signifikan \\
\hline
\end{tabular}


Berdasarkan tabel tersebut di atas, diketahui bahwa untuk kelompok Eksperimen diperoleh Nilai t Tes sebesar 54,66 dengan nilai probabilitas $0,00<0,05$. hasil tersebut berarti terdapat perbedaan yang signifikan antara proses pembelajaran SKI pada kelompok Eksperimen dan kelompok kontrol.

Nilai rata-rata kelompok eksperimen lebih tinggi dibandingkan dengan kelompok kontrol, berarti bahwa proses pembelajaran SKI lebih baik dibandingkan kelompok kontrol jadi berdasarkan hasil observasi yang telah dilakukan. proses pembelajaran SKI menggunakan media Film Umar bin Khattab pada kelompok Eksperimen lebih efektif dibandingkan dengan proses pembelajaran SKI dengan metode konvensional pada kelompok kontrol.

\section{Efektivitas Media Film Umar bin Khattab dalam Pembelajaran SKI ditinjau dari hasil angket}

Angket diberikan pada kelompok eksperimen setelah pembelajaran SKI menggunakan media film Umar bin Khattab selesai dilaksanakan. Hasil angket kemudian dianalisis menggunakan analisis statistic paired sample $t$ Tes untuk mengetahui efektivitas media Film Umar bin Khattab dalam pembelajaran SKI. Analisis dilakukan menggunakan komputer program SPSS dengan hasil sebagai berikut:

Tabel 13 Hasil Analisis Paired Sample t Test

\begin{tabular}{cccc}
\hline Kelompok & T Tes & P value & Keterangan \\
\hline Pre-test - Pos Tes & $-7,378$ & $0,000<0,05$ & Berbeda signifikan \\
\hline
\end{tabular}

Berdasarkan tabel tersebut di atas, diketahui bahwa nilai t test sebesar -7,378 dengan nilai probabilitas $0,000<0,05$. Hasil tersebut berarti terdapat perbedaan yang signifikan antara proses pembelajaran SKI sebelum dan sesudah penggunaan media film Umar bin Khattab. Nilai rata-rata Post-test lebih tinggi dibandingkan nilai Pre-test.

Ini berarti bahwa proses pembelajaran SKI lebih baik setelah digunakan media film Umar bin Khattab. jadi berdasarkan hasil angket yang diperoleh, proses pembelajaran SKI menggunakan media film Umar bin Khattab telah efektif dibandingkan dengan proses pembelajaran SKI dengan metode konvensional.

\section{Efektivitas Media Film Umar bin Khattab dalam Pembelajaran SKI ditinjau dari hasil tes}

Tes dilakukan pada dua kelompok baik kelompok baik kelompok eksperimen atau kelompok kontrol sebelum dan sesudah digunakan media film Umar bin Khattab. Tes ini digunakan untuk mengetahui dan membandingkan nilai siswa antara kelompok eksperimen yang diberikan perlakuan penggunaan media film Umar bin Khattab dengan nilai siswa kelompok kontrol. Analisis statistik paired sample $t$ Test menggunakan bantuan komputer program SPSS 22 for windows dan diperoleh hasil sebagai berikut: 
Tabel 14 Hasil Analisis Paired Sample t Test

\begin{tabular}{cccc}
\hline Kelompok & T Tes & P value & Keterangan \\
\hline Eksperimen & 10,633 & $0,000<0,05$ & Berbeda signifikan \\
Kontrol & 1,563 & $0,148>0,05$ & Tidak berbeda signifikan \\
\hline
\end{tabular}

Berdasarkan tabel tersebut di atas, diketahui bahwa untuk kelompok eksperimen diperoleh nilai t test sebesar 10,633 dengan nilai probabilitas 0,000<0,05. Hasil tersebut berarti terdapat perbedaan yang signifikan antara prestasi belajar sejarah kebudayaan Islam Pre-test dan Pos Tes

Hasil yang berbeda diperoleh dari kelompok kontrol. di mana kelompok ini tidak dikenai perlakuan penggunaan media film Umar bin Khattab efektif dalam pembelajaran SKI namun hanya menggunakan metode ceramah saja. Hasil $\mathrm{t}$ Tes yang diperoleh kelompok kontrol sebesar 1,563 dengan nilai probabilitas 0,067 >0,05. Hasil tersebut berarti tidak terdapat perbedaan yang signifikan antara prestasi belajar sejarah kebudayaan Islam Pre-test dan Post-test.

Berdasarkan hasil analisis paired sample $t$ Test tersebut diketahui bahwa prestasi belajar sejarah kebudayaan Islam pada siswa kelompok eksperimen berbeda signifikan antara Pre-test. Sedangkan untuk kelompok kontrol, prestasi belajar sejarah kebudayaan Islam siswa tidak berbeda antara Pre-test dan pos Tes.

Berdasarkan ketiga hasil analisis tersebut maka dapat disimpulkan bahwa hipotesis yang menyatakan penggunaan media film Umar bin Khattab efektif dalam pembelajaran SKI di MAN I Magelang dan dinyatakan diterima dan terbukti kebenarannya.

\section{Kesimpulan}

Berdasarkan deskripsi dan pembahasan hasil penelitian yang telah penulis kemukakan di atas maka efektivitas penggunaan media film dalam pembelajaran sejarah kebudayaan Islam di MAN I Magelang dapat disimpulkan bahwa penggunaan media film Umar bin Khattab dalam proses pembelajaran sejarah kebudayaan Islam di Madrasah Aliyah Negeri 1 Magelang memiliki tingkat efektivitas yang tinggi ditunjukkan dengan nilai observasi sebesar 52,5\%. nilai angket sebesar 62,5\% dan peningkatan hasil belajar dengan nilai rata-rata dari 78,7 pada Pre-test menjadi 81,2 pada saat post-test. Hal ini menunjukkan bahwa siswa lebih fokus dalam mengikuti proses pembelajaran yang disajikan melalui film Umar bin Khattab yang dapat diketahui pada saat ditayangkan film ini siswa cukup antusias memperhatikan sesekali mereka memberikan komentar pada beberapa adegan terutama adegan yang memperlihatkan kepribadian Umar bin Khattab di samping itu juga dapat dilihat dari pernyataan mereka bahwa pembelajaran sejarah kebudayaan Islam lebih inovatif, menarik dan menyenangkan sehingga mudah memahami dan menguasai materi secara lebih jelas. 


\section{Daftar Pustaka}

Abdurrahman. (2007). Meaningful Learning Re-Invensi Kebermaknaan Pembelajaran. Pustaka Pelajar.

Arikunto, S. (1998). Prosedur penelitian: Suatu pendekatan praktik. Rineka cipta.

Crabtree, C., \& Nash, G. B. (1994). National Standards for United States History: Exploring the American Experience. Grades 5-12. Expanded Edition. Including Examples of Student Achievement. ERIC.

Daradjat, Z. (2001). Remaja Harapan dan Tantangan. Ruhama.

Direktorat Pembinaan Sekolah Menengah. (2003). Pedoman Khusus Pengembangan Silabus Berbasis Kompetensi Sekolah Menengah Pertama (SMP) pada Mata Pelajaran Pendidikan Agama Islam Kurikulum 2004 Sekolah Menengah Pertama (SMP) (Jakarta). Departemen Pendidikan Nasional.

Hamid, H. S. (2003). Pendidikan IPS dan Ilmu Sosial di Masa Mendatang. Jurnal Pendidikan Ilmu Sosial, X(19).

Idris, J. (2005). Kompilasi pemikiran pendidikan. Suluh Press.

Ismaun. (2001). Paradigma Pendidikan Sejarah yang Terarah dan Bermakna. Historia: Jurnal Pendidikan Sejarah, II(Desember 2001), 88-115.

Muharria, M., Yusuf, S., \& Kartika, S. (2016). Pengaruh Penerapan Media Film Pendek Sebagai Sumber Pembelajaran Sejarah Terhadap Hasil Belajar Siswa di Kelas X Matematika Ilmu Alam Sekolah Menengah Atas Negeri 13 Palembang. Criksetra: Jurnal Pendidikan Sejarah, 5(1)

Resmiati, S. S. (2010). Pengaruh Media Film Dokumenter Sejarah Dan Motivasi Belajar Terhadap Prestasi Belajar Mata Pelajaran Sejarah Pada Siswa Kelas XI SMA Negeri Di Kabupaten Purworejo [Thesis, UNS (Sebelas Maret University)].

Sukandarrumidi. (2002). Metodologi Penelitian Petunjuk Praktis untuk Peneliti Pemula. Gadjah Mada University Press.

Widja, I. G. (2002). Menuju wajah baru pendidikan sejarah. Lappera Pustaka Utama.

Wiriaatmadja, R. (2002). Pendidikan Sejarah di Indonesia: Perspektif Lokal, Nasional, dan Global. Historia Utama Press.

Zuhairini. (2003). Metodik Khusus Pendidikan Agama. Usaha Nasional. 